\title{
The relationship between preschool teachers' self-efficacy beliefs and their teaching attitudes
}

\author{
Kamil Arif Kırkıç ${ }^{1}$, Fatma Çetinkaya ${ }^{2}$ \\ ${ }^{1}$ Department of Educational Sciences, İstanbul Sabahattin Zaim University, Turkey \\ ${ }^{2}$ Ministry of Education, Turkey
}

\section{Article Info \\ Article history: \\ Received Apr 15, 2020 \\ Revised Aug 20, 2020 \\ Accepted Oct 22, 2020}

\section{Keywords:}

Preschool teacher Self-efficacy belief Teaching attitudes

\begin{abstract}
This study examined the relationship between preschool teachers' selfefficacy beliefs and their teaching attitudes. In the study, it was considered whether preschool teachers' self-efficacy beliefs and their teaching attitudes change in terms of certain variables. The research was carried out using a correlational survey model. The target population of the study is the preschool teachers working in Küçükçekmece district, İstanbul Province, in the 2017-2018 academic year. The working group consists of 264 preschool teachers working at the schools in said district. The following assessment instruments were used in the research: "Personal Information Form," "Preschool Teachers' Self-efficacy Beliefs Scale," to identify preschool teachers' self-efficacy beliefs and 'Preschool Teachers' Teaching Attitudes Scale' to determine the teachers' attitudes. The obtained data were analyzed using Pearson multiplication moment correlation analysis, and Regression analysis was performed to determine the level of self-efficacy beliefs of preschool teachers affecting teaching attitudes. Preschool teachers were found to have full self-efficacy beliefs in the teaching-learning process, communication skills, planning, and regulation of learning environments and classroom management, and firm self-efficacy beliefs in family participation. Teachers' attitudes of preschool teachers were found to be democratic at the highest level, followed by autocratic and laissez-faire at the lowest level. As a result of the regression analysis made to determine the level of the effect of self-efficacy beliefs of preschool teachers on their teaching attitudes, the learning and teaching process positively predicts democratic teaching attitudes and negatively predicts laissez-faire attitudes.
\end{abstract}

This is an open access article under the CC BY-SA license.

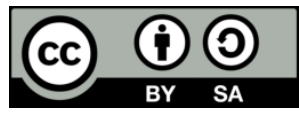

\section{Corresponding Author:}

Kamil Arif Kırkıç,

Department of Educational Sciences,

İstanbul Sabahattin Zaim University,

Halkalı Kampüsü Halkalı Caddesi, Küçükçekmece/İstanbul, Turkey.

Email: kamil.kirkic@izu.edu.tr

\section{INTRODUCTION}

Teachers who play an essential role in shaping societies should be able to meet the necessities of the time in order to educate new generations. The social and economic development and progress of the countries require teachers to be trained and their students educated in a qualified manner; they should be professionally and personally equipped individuals who are open to change, productive, and sensitive to the situations around them. They must have specific competencies and follow progress. Teaching is a profession of great importance that builds the future of societies [1]. The teacher is the most fundamental element of the education system. Teachers play the most prominent role in the development of countries, bringing qualified 
people to society, enabling the individuals to socialize and preparing them for the life of the community, transferring the culture and social values of the society in which they live to the new generations [2]. It is thought that the quality of teachers is of great importance for the effectiveness and success of education. Nowadays, teachers are expected to guide their students' development rather than transferring knowledge and turn to practice rather than theory. Teachers should not only be competent in their fields but also need to find solutions to the students' problems. Behaviors that will benefit society and are in line with the moral structure of the nation should be established at an early age. Students take the teacher's example by assimilating the behaviors they observe from their teachers. In the eyes of the student, the teacher knows the truth and acts accordingly. Teacher's practice with the students is an essential criterion in their success [3]. Teachers, who have an active role in education should have full self-confidence. Teachers who have the qualifications required by their profession can realize the training they receive with the awareness of their duties and belief that they can fulfill their responsibilities altogether. This is the belief of self-efficacy [4].

Teachers with high self-efficacy beliefs believe that they can increase students' success and motivation and at least have a positive effect [5-7]. It was found that the teachers' self-efficacy levels differed in the feedback given to students who had difficulties in learning, and consequently, teachers' self-efficacy affected student success and motivation. Teachers' self-efficacy has a positive effect on student achievement as well as the teacher's movements in the classroom, openness to innovations, and development of positive behaviors towards teaching activities [8-12]. Attitudes are of great importance in shaping personality, emotions, thoughts, and behaviors. The views of the teachers, who play an essential role in the formation of the character of students, towards the environment and teaching are critical.

Teachers' attitudes are reflected in their behaviors in the classroom and the classroom practices [13-16]. One of the most critical conditions for the teacher to be able to teach effectively and to be happy with his or her job is that his or her attitude towards the teaching profession is positive [17, 18]. Positive attitudes in the teaching profession can be summarized as being interested in teaching, taking care of teaching environments, and loving and appreciating students. Positive teaching attitudes increase the effectiveness of learning environments and facilitate learning. Although the self-efficacy levels of teachers affect their job satisfaction [19-21] on the other hand, negative views of teachers are seen as one of the obstacles in front of education and training goals [22]. Teachers who can update their professional competencies according to the necessities of the time show a positive attitude in their profession by evaluating their self-efficacy objectively; they try to complete their shortcomings. Therefore, it is possible to mention that there is a relationship between teachers' self-efficacy beliefs and attitudes [23-27]. On the other hand, there is no relationship between self-efficacy levels and attitudes toward the profession [28, 29]. The importance of self-efficacy beliefs and professional attitudes of teachers, especially preschool teachers who constitute the first step in shaping the future, and the necessity of examining their self-efficacy belief levels and teaching attitudes led to this research.

When the literature is examined, it is seen that there are many types of studies about teacher selfefficacy and attitudes. However, few studies are investigating both concepts together. Therefore, to overcome this absence in the field, this study, which examines the relationship between preschool teachers' selfefficacy beliefs and teaching attitudes, has been carried out with the assumption that it will contribute to the field and provide suggestions for future research. This research is vital in determining the relationship between self-efficacy belief levels and teaching attitudes of preschool teachers working in independent preschool institutions and kindergartens within other schools. Besides, it is crucial to determine whether preschool teachers' self-efficacy levels and teaching attitudes differ according to the variables of age, graduation status, professional seniority, types of school worked, working status, age group, and class size. It will also provide an opportunity to see the possible relationship between teacher self-efficacy levels and teaching attitudes. Moreover, it is thought that teachers can offer useful suggestions to the Ministry of National Education and education administrators to identify the self-efficacy beliefs of teachers and to overcome the shortcomings that may arise. This study was conducted to examine the relationship between preschool teachers' self-efficacy beliefs and teaching attitudes and to see whether there is a significant relationship between them. In this direction, the main question the research asks is whether there is a meaningful relationship between preschool teachers' self-efficacy beliefs and teaching attitudes.

\section{RESEARCH METHOD}

In this section, information is given about the research model, universe and sample, data collection tools, data collection, and analysis. 


\subsection{Research model}

This research is aimed to investigate the relationship between preschool teachers' self-efficacy beliefs and teaching attitudes. Survey models are research approaches that aim to describe a past or present situation as it exists. The subject is tried to be defined in its conditions and as it is. There is no attempt to change or influence them in any way. Relational survey models are research models aiming to determine the existence and degree of co-change between two and more variables. In relational surveys, it is tried to find out whether the variables change together or if there is a change together, how it occurs [30].

\subsection{Research group}

The population of the research consists of 596 teachers working in official independent kindergartens and kindergartens of official primary, secondary, and high schools in Küçükçekmece district of İstanbul in the 2017-2018 academic year. In the process of conducting the research, instead of reaching all the teachers in the study universe, it was decided to select a sample from the study universe to save time, energy, and economics. The number of teachers to be included in the study sample was calculated using the sample calculation program from the Raosoft website [31]. Although the number of teachers to be sampled was found to be at least 234, according to the calculation, 264 teachers were reached and evaluated. In this study, a simple random sampling method was used. The demographics of preschool teachers participating in the study are presented in Table 1 .

Table 1. Findings regarding demographic characteristics of participants

\begin{tabular}{clcc}
\hline & Demographic properties & Frequency & Percentage (\%) \\
\hline \multirow{5}{*}{ Age } & 25 and under & 51 & 19.3 \\
& Between 26-30 & 91 & 34.5 \\
& Between 31-35 & 63 & 23.9 \\
& 36 and over & 59 & 22.3 \\
& Total & 264 & 100 \\
& Assoc. Degree & 71 & 26.9 \\
Education & Bachelor's Degree & 185 & 70.1 \\
& Postgraduate Degree & 8 & 3.0 \\
& Total & 264 & 100 \\
Professional & Five years and under & 98 & 37.1 \\
seniority (Years) & Between 6-10 years & 112 & 42.4 \\
& 11 years and over & 54 & 20.5 \\
& Total & 264 & 100 \\
& Independent Preschool & 150 & 56.8 \\
School type & Preschool within Primary School & 72 & 27.3 \\
& Preschool within Middle School & 29 & 11.0 \\
& Preschool within High School & 13 & 4.9 \\
& Total & 264 & 100 \\
& Permanent & 162 & 61.4 \\
Employment type & Contracted/Paid & 102 & 38.6 \\
& Total & 264 & 100 \\
& Three years old & 30 & 11.4 \\
Student age group & Four years old & 71 & 26.9 \\
& Five years old & 163 & 61.7 \\
& Total & 264 & 100 \\
& Between 10-15 & 54 & 20.5 \\
Number of students & Between 16-20 & 114 & 43.2 \\
in class & Between 21-25 & 83 & 31.4 \\
& 26 and over & 13 & 4.9 \\
& Total & 264 & 100 \\
\hline \multirow{5}{*}{ (Y) } & &
\end{tabular}

As shown in Table 1, when the teachers participating in the study were examined by age group, 51 (19.3\%) were between 25 and under, 91 (34.5\%) were between 26-30, 63 (23.9\%) were between $31-35$ and $59(22.3 \%)$ were in the age group of 36 and over. $71(26.9 \%)$ of the teachers had associate degrees, 185 (70.1\%) had bachelor's degrees, and $8(3.0 \%)$ had postgraduate degrees. $98(37.1 \%)$ of the teachers had five years of professional experience or less, $112(42.4 \%)$ of them had 6-10 years, $54(20.5 \%)$ of them had 11 years. When the teachers were examined according to the type of school they work, it was seen that 150 $(56.8 \%)$ work in independent kindergartens, 72 (27.3\%) work in kindergartens within primary schools, 29 $(11.0 \%)$ work in kindergartens within middle schools and $13(4.9 \%)$ work in kindergartens within high schools. $162(51.4 \%)$ of the teachers are permanent, and $102(38.6 \%)$ are contracted or paid teachers. 30 $(11.4 \%)$ of the teachers teach 3-year-old students, 71 (26.9\%) teach 4-year-old students and $163(61.7 \%)$ teach 5-year-old students. When the teachers were examined according to the number of students in their 
classes, 54 (20.5\%) had between 10-15, 114 (43.2\%) had between 16-20, 83 (31.4\%) had between 21-25 and $13(4.9 \%)$ teach in classes with 26 and over students.

\subsection{Data collection tools}

A data collection tool consisting of three parts was used in the study. In the first part, the research aims to explain the confidentiality of the answers and that they will be used for academic purposes. The information includes age, the most recent educational institution, year of professional seniority, and type of school worked in, working status, age group, and the number of students in the class. In the second part, the Self-Efficacy Beliefs Scale of Preschool Teachers developed by Tepe was used [32]. Five-point Likert-type scale is rated as 1) None, 2) Low, 3) Average, 4) High, and 5) Full. The total variance explained by the first factor is $14.81 \%$; the total variance ratio defined by the second factor is $12 \%, 51$, the third factor explained the overall variance rate of $11.34 \%$, the fourth factor explained the total variance rate of $9.96 \%$, the fifth factor explained the total variance rate of $8.36 \%$, the sixth factor explained the overall variance rate of $8.02 \%$ and the total variance is $64.99 \%$. The scale has a factor load of $0.54-0.71$ for the teaching and learning process, $0.55-0.78$ for the communication skills factor, $0.70-0.80$ for the family participation factor, $0.56-0.71$ for the planning factor, $0.57-0.68$ for the regulation of learning environments factor and $0.45-0.69$ for the classroom management factor. The six-factor scale consists of 37 items; nine of them were in the first factor, seven of them were in the second factor, five of them were in the third factor, six of them were in the fourth factor, five of them were in the fifth factor, and five of them were in the sixth factor. The differences observed in favor of the upper group between the averages of the lower $27 \%$ and the top $27 \%$ were significant for all items. In this direction, it was accepted that the self-efficacy beliefs scale of the preschool teachers had a validity based on the internal criterion. In the third part, Teaching Attitudes of Preschool Teachers Scale developed by Bilgin was used [33]. The teacher attitudes scale was adapted from the Minnesota Teacher Attitude Inventory, which was developed in 1951 by Leeds as the first teacher attitude inventory and then re-adapted by Callis. The five-point Likert-type scale was rated as 5) I fully agree, 4) I mostly agree, 3) I am undecided, 2) I strongly disagree, and 1) I do not agree at all. The scale consists of three sub-dimensions: autocratic attitude, democratic attitude, and laissez-faire attitude and a total of 52 items. In the study, Cronbach's alpha values were found to be .70 for the autocratic attitude sub-dimension, .58 for the democratic attitude sub-dimension, .66 for the laissez-faire attitude sub-dimension and .63 for the whole scale.

\subsection{Data collection}

To use the scales, the permissions obtained from those who developed the scales were obtained from the Istanbul Provincial Directorate of National Education to apply the questionnaire as a data collection tool to the teachers in the sample. The researcher has conducted the sampling for the survey during the 2 nd semester of the 2017-2018 academic year by going to the schools within the scope of the study.

\subsection{Data analysis}

The applied scales were numbered from 1 to 264. There are no reverse coded items in the SelfEfficacy Beliefs Scale of Preschool Teachers and Preschool Teacher Attitudes Scale. SPSS (Statistical Package for the Social Sciences) program was used to analyze the data obtained as follows. Pearson Product Moment Correlation Analysis was used to determine the relationship between preschool teachers' selfefficacy beliefs and teaching attitudes. Regression analysis was performed to determine the level of selfefficacy beliefs of preschool teachers affecting teaching attitudes. Skewness and kurtosis values were examined to determine whether the data showed normal distribution and these values were calculated as -.43 and -1.02 for the "learning and teaching process" subscale of the self-efficacy beliefs scale of the preschool teachers, -1.04 and .28 for the "communication skills" sub-dimension, -.58 and -.10 for the "family participation" sub-dimension, -.63 and .01 for the "planning" sub-dimension, -.51 and -.35 for the "regulation of learning environments" sub-dimension, - .55 and -.19 for the "classroom management" sub-dimension, and -.54 and .03 for the whole scale. The skewness and kurtosis values of preschool teachers' teaching attitudes scale were -.83 and 1.15 for the "democratic attitude" sub-dimension, -.08, and .06 for the "autocratic attitude" sub-dimension, and .85 and .79 for the "laissez-faire attitude" sub-dimension, respectively. Skewness and kurtosis values are considered acceptable for normality within the \pm 1.5 gap, according to Tabachnick and Fidell [34] and \pm 2 , according to George and Mallery [35]. Therefore, the distribution was considered normal. 


\section{RESULTS AND DISCUSSION}

\subsection{Results}

As can be seen in Table 2, when the preschool teachers' teaching attitude scale subscales were examined, the mean of the "democratic attitude" sub-dimension scores was ${ }^{-} \mathrm{x}=4.15$; the mean of "autocratic attitude" sub-dimension was ${ }^{-} \mathrm{x}=2.45$, and the mean of the "laissez-faire attitude" subscale scores was ${ }^{-} \mathrm{x}=1.88$. According to these results, preschool teachers stated that they mostly had democratic attitudes towards students $(-\mathrm{x}=4.15)$, followed by autocratic attitudes $(-\mathrm{x}=2.45)$ and finally, "laissez-faire" attitudes $\left({ }^{-} \mathrm{x}=1.88\right)$. In Table 3 , it is tried to determine whether there is a significant relationship between the preschool teachers' self-efficacy beliefs and teaching attitudes. The data obtained from the teachers' responses to the scale were examined and presented with Pearson Correlation Analysis.

Table 2. Preschool teachers' teaching attitudes scale and arithmetic mean, standard deviation and standard error values of sub-dimensions

\begin{tabular}{ccccc}
\hline Dimensions & $\mathrm{n}$ & $\overline{\mathrm{x}}$ & $\mathrm{Sd}$ & $\mathrm{S} . \mathrm{E}_{\overline{\mathrm{x}}}$ \\
\hline Democratic Attitude & 264 & 4.15 & .44 & .03 \\
Autocratic Attitude & 264 & 2.45 & .50 & .03 \\
Laissez-Faire Attitude & 264 & 1.88 & .42 & .03 \\
\hline
\end{tabular}

Table 3. The results of Pearson correlation analysis to determine the relationship between self-efficacy beliefs and teaching attitudes of preschool teachers

\begin{tabular}{ccccccccc}
\hline Dimensions & $\begin{array}{c}\text { Learning- } \\
\text { Teaching } \\
\text { Process }\end{array}$ & $\begin{array}{c}\text { Communication } \\
\text { Skills }\end{array}$ & $\begin{array}{c}\text { Family } \\
\text { Participation }\end{array}$ & Planning & $\begin{array}{c}\text { Regulation of } \\
\text { Learning } \\
\text { Environments }\end{array}$ & $\begin{array}{c}\text { Classroom } \\
\text { Management }\end{array}$ & $\begin{array}{c}\text { Scale } \\
\text { Total }\end{array}$ \\
\hline Democratic & $\mathrm{r}$ & .228 & .251 & .181 & .245 & .169 & .164 & .254 \\
Attitude & $\mathrm{p}$ & .000 & .000 & .003 & .000 & .006 & .008 & .000 \\
Autocratic & $\mathrm{r}$ & -.118 & -.088 & -.137 & -.092 & -.079 & -.066 & -.122 \\
Attitude & $\mathrm{p}$ & .057 & .154 & .026 & .136 & .200 & .283 & .048 \\
Laissez-Faire & $\mathrm{r}$ & -.251 & -.241 & -.311 & -.236 & -.261 & -.227 & -.312 \\
Attitude & $\mathrm{p}$ & .000 & .000 & .000 & .000 & .000 & .000 \\
\hline
\end{tabular}

As can be seen in Table 3, the Pearson correlation analysis on whether there is a significant relationship between the subscale dimensions of preschool teachers' self-efficacy beliefs and the subscale dimensions of the teaching attitude scale shows that: There is a significant and statistically low positive correlation between "democratic attitude" and "learning and teaching process" $(r=.228 ; p<.05)$. There is a significant and statistically low positive correlation between "Democratic attitude" and "communication skills" ( $\mathrm{r}=.251 ; \mathrm{p}<.05)$. There is a significant and statistically low positive correlation between "democratic attitude" and "family participation" $(\mathrm{r}=.181 ; \mathrm{p}<.05)$. There is a significant and statistically low positive correlation between "democratic attitude" and "planning" $(\mathrm{r}=.245 ; \mathrm{p}<.05)$. There is a significant and statistically low positive correlation between "democratic attitude" and regulation of learning environments ( $\mathrm{r}$ $=.169 ; \mathrm{p}<.05)$. There is a significant and statistically low positive correlation between "democratic attitude" and "classroom management" $(\mathrm{r}=.164 ; \mathrm{p}<.05)$. There is a significant and statistically low positive correlation between "democratic attitude" and teachers' self-efficacy beliefs scale $(r=.254 ; \mathrm{p}<.05)$. There is a significant and statistically low negative correlation between "autocratic attitude" and "family participation" ( $\mathrm{r}=-.137 ; \mathrm{p}<.05)$. There is a significant and statistically low negative correlation between "autocratic attitude" and teachers' self-efficacy beliefs scale total $(r=-.122 ; \mathrm{p}<.05)$. There is a statistically significant negative correlation between the "laissez-faire attitude" and "learning-teaching process $((\mathrm{r}=-$ $.251 ; \mathrm{p}<.05)$. There is a statistically significant negative correlation between "laissez-faire attitude" and "communication skills" $((\mathrm{r}=-.241 ; \mathrm{p}<.05)$. There was a statistically significant negative relationship between "laissez-faire attitude" and "family participation" $((\mathrm{r}=-.311 ; \mathrm{p}<.05)$. There is a statistically significant negative correlation between "laissez-faire attitude" and "planning" ( $(\mathrm{r}=-.236 ; \mathrm{p}<.05)$. There was a statistically significant negative correlation between "laissez-faire attitude" and "regulation of learning environments" $\mathrm{r}(\mathrm{r}=-.261 ; \mathrm{p}<.05)$. There was a statistically significant negative relationship between "laissez-faire attitude" and "classroom management" ( $\mathrm{r}=-.227 ; \mathrm{p}<.05)$. There was a significant and statistically low negative correlation between "laissez-faire attitude" and total self-efficacy belief scale $(r=-$ $.312 ; \mathrm{p}<.05)$

In Table 4, it was tried to determine how strongly are the teaching attitudes of teachers are affected by their self-efficacy beliefs. In order to answer this question, the data obtained from the teachers' responses to the scale were examined and presented with Regression analysis. Table 4 shows that as a result of the regression analysis made to determine the level of the effect of self-efficacy beliefs of preschool teachers on 
their teaching attitudes; learning and teaching process positively predicts democratic teaching attitudes $\left(\mathrm{R}^{2}=\right.$ $.052 ; \mathrm{p}<.05)$ and negatively predicts laissez-faire attitudes $\left(\mathrm{R}^{2}=.063 ; \mathrm{p}<.05\right)$. The learning-teaching process explains $5.2 \%$ of the total variance in teachers' democratic teaching attitude levels and $6.3 \%$ of the total variance of teachers' laissez-faire teaching attitude levels. It is seen that communication skills positively predict democratic teaching attitudes $\left(\mathrm{R}^{2}=.063 ; \mathrm{p}<.05\right)$, and negatively predict laissez-faire attitudes $\left(\mathrm{R}^{2}=\right.$ $.058 ; \mathrm{p}<.05)$. Communication skills explain $6.3 \%$ of the total variance in teachers' democratic teaching attitude levels and $6.3 \%$ of the total variation of laissez-faire attitude levels. Family participation positively predicts democratic teaching attitudes $\left(\mathrm{R}^{2}=.033 ; \mathrm{p}<.05\right)$, negatively predict autocratic teaching attitudes $\left(\mathrm{R}^{2}\right.$ $=.019 ; \mathrm{p}<.05)$ and laissez-faire teaching attitudes $\left(\mathrm{R}^{2}=.097 ; \mathrm{p}<.05\right)$. Family participation explains $3.3 \%$ of the total variance of teachers' democratic teaching attitude levels, $1.9 \%$ of the total variance of autocratic teaching attitude levels, and $9.7 \%$ of the total variance of laissez-faire teacher attitude levels. It is seen that planning predicts democratic teaching attitudes $\left(\mathrm{R}^{2}=.060 ; \mathrm{p}<.05\right)$ positively and laissez-faire teaching attitudes negatively $\left(\mathrm{R}^{2}=.055 ; \mathrm{p}<.05\right)$. Planning explains $6.0 \%$ of the total variance of teachers' democratic teaching attitude levels and $5.5 \%$ of the total variance at the level of laissez-faire attitude levels. It is seen that the regulation of learning environments positively predicts democratic teaching attitudes $\left(\mathrm{R}^{2}=.029 ; \mathrm{p}<.05\right)$ negatively predicts laissez-faire teaching attitudes $\left(\mathrm{R}^{2}=.068 ; \mathrm{p}<.05\right)$. The regulation of learning environments explains $2.9 \%$ of the total variance of teachers' democratic teaching attitude levels and $6.8 \%$ of the total variance of laissez-faire attitude levels. It is seen that classroom management positively predicts democratic teaching attitudes $\left(\mathrm{R}^{2}=.027 ; \mathrm{p}<.05\right)$, and negatively predicts laissez-faire teaching attitudes $\left(\mathrm{R}^{2}\right.$ $=.052 ; \mathrm{p}<.05)$. Classroom management explains $2.7 \%$ of the total variance of teachers' democratic teaching attitude levels and $5.2 \%$ of the total variation in the level of laissez-faire teacher attitude levels. Teachers' self-efficacy perceptions positively predict democratic teaching attitudes $\left(\mathrm{R}^{2}=.064 ; \mathrm{p}<.05\right)$; negatively predict both autocratic teaching attitudes $\left(\mathrm{R}^{2}=.015 ; \mathrm{p}<.05\right)$ and laissez-faire teaching attitudes $\left(\mathrm{R}^{2}=.097 ; \mathrm{p}\right.$ $<.05)$. Self-efficacy perceptions of teachers explain $6.4 \%$ of the total variance of democratic teaching attitude levels, $1.5 \%$ of the total variance of autocratic teaching attitude levels, and $9.7 \%$ of the total variance of laissez-faire teacher attitude levels.

Table 4. The results of regression analysis on whether preschool teachers' self-efficacy beliefs predict teacher

\begin{tabular}{|c|c|c|c|c|c|c|c|c|c|c|}
\hline $\begin{array}{l}\text { Independent } \\
\text { Variable }\end{array}$ & Dependent Variable & B & $\begin{array}{l}\text { Std. } \\
\text { Error }\end{array}$ & $(\beta)$ & $\mathrm{t}$ & $\mathrm{p}$ & $\mathrm{R}$ & $\mathrm{R}^{2}$ & $\mathrm{~F}$ & $\mathrm{p}$ \\
\hline Learning- & Democratic Attitude & .23 & .06 & .23 & 3.796 & .000 & .228 & .052 & 14.407 & .000 \\
\hline Teaching & Autocratic Attitude & -.13 & .07 & -.12 & -1.915 & .057 & .118 & .014 & 3.668 & .057 \\
\hline Process & Laissez-Faire Attitude & -.24 & .06 & -.25 & -4.203 & .000 & .251 & .063 & 17.666 & .000 \\
\hline \multirow{3}{*}{$\begin{array}{l}\text { Communication } \\
\text { Skills }\end{array}$} & Democratic Attitude & .29 & .07 & .25 & 4.204 & .000 & .251 & .063 & 17.677 & .000 \\
\hline & Autocratic Attitude & -.12 & .08 & -.09 & -1.428 & .154 & .088 & .008 & 2.040 & .154 \\
\hline & Laissez-Faire Attitude & -.27 & .07 & -.24 & -4.026 & .000 & .241 & .058 & 16.209 & .000 \\
\hline \multirow{3}{*}{$\begin{array}{c}\text { Family } \\
\text { Participation }\end{array}$} & Democratic Attitude & .12 & .04 & .18 & 2.983 & .003 & .181 & .033 & 8.897 & .003 \\
\hline & Autocratic Attitude & -.10 & .05 & -.14 & -2.24 & .026 & .100 & .019 & 5.019 & .026 \\
\hline & Laissez-Faire Attitude & -.20 & .04 & -.31 & -5.29 & .000 & .311 & .097 & 28.023 & .000 \\
\hline \multirow{3}{*}{ Planning } & Democratic Attitude & .21 & .05 & .25 & 4.083 & .000 & .245 & .060 & 16.670 & .000 \\
\hline & Autocratic Attitude & -.09 & .06 & -.09 & -1.497 & .136 & .092 & .008 & 2.240 & .136 \\
\hline & Laissez-Faire Attitude & -.19 & .05 & -.24 & -3.923 & .000 & .236 & .055 & 15.388 & .000 \\
\hline \multirow{3}{*}{$\begin{array}{l}\text { Regulation of } \\
\text { Learning } \\
\text { Environments }\end{array}$} & Democratic Attitude & .14 & .05 & .17 & 2.776 & .006 & .169 & .029 & 7.706 & .006 \\
\hline & Autocratic Attitude & -.07 & .06 & -.08 & -1.283 & .200 & .079 & .006 & 1.647 & .200 \\
\hline & Laissez-Faire Attitude & -.21 & .05 & -.26 & -4.376 & .000 & .261 & .068 & 19.145 & .000 \\
\hline \multirow{3}{*}{$\begin{array}{l}\text { Classroom } \\
\text { Management }\end{array}$} & Democratic Attitude & .15 & .06 & .16 & 2.69 & .008 & .164 & .027 & 7.254 & .008 \\
\hline & Autocratic Attitude & -.07 & .06 & -.07 & -1.077 & .283 & .066 & .004 & 1.160 & .283 \\
\hline & Laissez-Faire Attitude & -.19 & .05 & -.23 & -3.779 & .000 & .227 & .052 & 14.281 & .000 \\
\hline \multirow{3}{*}{ Scale Total } & Democratic Attitude & .28 & .07 & .25 & 4.248 & .000 & .254 & .064 & 18.044 & .000 \\
\hline & Autocratic Attitude & -.15 & .08 & -.12 & -1.983 & .048 & .122 & .015 & 3.934 & .048 \\
\hline & Laissez-Faire Attitude & -.33 & .06 & -.31 & -5.317 & .000 & .312 & .097 & 28.270 & .000 \\
\hline
\end{tabular}

\subsection{Discussion}

Preschool teachers generally have full self-efficacy beliefs. Preschool teachers were found to have full self-efficacy beliefs in the teaching-learning process, communication skills, planning, and regulation of learning environments and classroom management, and firm self-efficacy beliefs in family participation. Similarly, Emre found that secondary school teachers' self-efficacy perceptions of classroom management were sufficient [36]. Daştan, in her research with preschool teachers, has a high level of family participation, top self-efficacy beliefs in the teaching-learning process, communication skills, planning, regulation of learning environments, and classroom management [37]. Toy showed that classroom teachers' general self- 
efficacy beliefs and student participation, teaching strategies, and self-efficacy beliefs towards classroom management were quite sufficient [38]; Korkut found that classroom teachers' self-efficacy beliefs were quite high [39]. Teachers' attitudes of preschool teachers were found to be democratic at the highest level, followed by autocratic and laissez-faire at the lowest level. Töre found that school climate significantly and positively affects on the knowledge management process such as knowledge production and sharing, knowledge storage and use, knowledge collection [40]. In addition to Gürsoy found that preschool teachers mostly showed democratic attitudes [41]. It can be thought that the school climate in which teachers work in general is democratic and that they perform their jobs with love. Educational institutions can contribute to the professional development of teachers by using their resources. Teachers working in the institution can include professional development studies to the extent of their competence. Therefore, the acceptance and understanding of the study from teachers will be facilitated [42].

There was a significant and statistically medium positive correlation between democratic teaching attitudes of preschool teachers and learning-teaching process, communication skills, family participation, planning, planning of learning environments, classroom management sub-dimensions, and total scale. A significant and statistically low level of negative correlation was found between autocratic teaching attitudes of preschool teachers and learning-teaching process, communication skills, family participation, planning, planning of learning environments, classroom management sub-dimensions, and overall scale total. A significant and statistically low level of negative correlation was found between preschool teachers' laissezfaire teaching attitudes, learning, and teaching process, communication skills, family participation, planning, planning of learning environments, classroom management sub-dimensions, and total scale. The results of the research show that there is a positive relationship between democratic teaching attitudes and the teachers' beliefs in self-efficacy and their sub-dimensions, while a negative relationship occurs between those and autocratic/ laissez-faire teaching attitudes. This is considered to be because most teachers have democratic attitudes, as this is the type of attitude expected/desired from them. According to this result, the teachers' democratic attitudes increase with the increase in their self-efficacy levels in the learning process, communication skills, family participation, planning, and regulation of learning environments, classroom management, and scale total. Whereas their autocratic teaching attitudes decrease as self-efficacy in family participation increases, and their laissez-faire attitudes decrease as their self-efficacy increases concerning the learning process, communication skills, family participation, planning, regulation of learning environments, classroom management and scale total. Similar to these findings, Töre found that self-efficacy affects the innovative work behavior significantly and positively [43].

\section{CONCLUSION}

According to the results, the relationship between preschool teachers' self-efficacy beliefs and teaching attitudes is significant. Therefore, to improve teachers' teaching attitudes, their self-efficacy levels should be increased by using different approaches and techniques. Since the teachers' democratic attitudes increase with the increase in their self-efficacy levels in the learning process, communication skills, family participation, planning, regulation of learning environments, classroom management, and scale total, teachers' self-efficacy beliefs should be taken in to account by school principals. If there were any problems in teachers' attitudes, it would be better to look at teachers' self-efficacy levels and help them to improve their self-efficacy beliefs. It is possible to study what factors predict teachers' democratic, autocratic, and laissez-faire teaching attitudes other than their self-efficacy beliefs. Furthermore, for pre-service and inservice teacher training processes, new programs may be developed to improve teachers' teaching attitudes by improving their self-efficacy beliefs.

\section{ACKNOWLEDGEMENTS}

This research is based on the second author's master's thesis, which was conducted under the supervision of the first author.

\section{REFERENCES}

[1] Z. Göktaş and A. Yetim, "Teacher's Occupational and Personal Qualifications," Kastamonu Education Journal, vol. 12, no. 2, pp. 541-550, 2004.

[2] Y. Özden, Transformation in education new values in education, Ankara: PegemA, 2002.

[3] Ç. Karahan, "The observation of self-perception and job satisfaction of the secondary level elementary teachers," (Unpublished Masters Thesis), Ege University, İzmir, 2006.

[4] M. Yilmaz, P. Köseoğlu, C. Gerçek, and H. Soran, “Adaptation of a teacher self-efficacy scale to Turkish," Hacettepe University Journal of Faculty of Education, no. 27, pp. 260-267, 2004. 
[5] Ü.K. Açıkgöz, Effective learning and teaching. İzmir: Kanyılmaz Printing, 1996.

[6] M. Tschannen-Moran, A. W. Hoy, and W. K. Hoy, "Teacher efficacy: Its meaning and Measure," Review of Educational Research, vol. 68, no. 2, pp. 202-248, 1998.

[7] A. Bandura, Self-Efficacy, the exercise of control, New York: W. H. Freeman and Company, 1997.

[8] Ministry of National Education, MoNE, "General competencies of the teaching profession," Ankara, pp. 1-16, 2017. [Online]. Available: http://oygm.meb.gov.tr/meb_iys_dosyalar/2017_12/11115355_YYRETMENLYK_ MESLEYY_GENEL_YETERLYKLERY.pdf

[9] S. Yaman, Ö. Cansüngü, and A. Altunçekiç, "A research on the investigation of the self-sufficiency belief levels of the science education teacher candidates," The Journal of Turkish Educational Sciences, vol. 2, no. 3, pp. 355-364, 2004.

[10] A. Gürol, S. Altınbaş, and N. Karaaslan, "A study of self-efficacy and epistemological beliefs of prospective teachers," e-Journal of New World Sciences Academy, vol. 5, no. 3, pp. 1395-1404, 2010.

[11] M. N. Gömleksiz and B. Serhatlığlu, "Preschool teachers' perceptions of self-efficacy beliefs," Electronic Turkish Studies, vol. 8, no. 7, pp. 201-221, 2013.

[12] D. Holzberger, A. Philipp, and M. Kunter, "How Teachers' Self-Efficacy Is Related to Instructional Quality: A Longitudinal Analysis," Goethe University Frankfurt Journal of Educational, vol. 105, no. 3, pp. 774-786, 2013.

[13] H. Demirtaş, M. Cömert, and N. Özer, "Pre-service teachers' self-efficacy beliefs and attitudes towards the profession," Education and Science, vol. 36, no. 159, pp. 103-107, 2011.

[14] M. N. Suprayogi, M. Valcke and R. Godwin, "Teachers and their implementation of differentiated instruction in the classroom," Teaching and Teacher Education, vol. 67, pp. 291-301, Oct. 2017.

[15] Y. Guo, M. Justice, B. Sawyer, and V. Tompkins, "Exploring factors related to preschool teachers' self-efficacy," Teaching and Teacher Education, vol. 27, no. 5, pp. 961-968, 2011.

[16] Ö. Özkan, C. Tekkaya, and J. Çakıroğlu, "Science Teachers' Understanding Of Science Concepts, Attitudes Towards Science Teaching and Self-Efficacy Beliefs (in Turkish)," V. National Science and Mathematics Education Congress, ODTÜ- Ankara, 2002.

[17] M. Üstüner, "Reliability and validity study of an attitude scale of the teaching profession," Educational Administration: Theory and Practice, vol. 45, pp. 109-127, 2006.

[18] A. D. Miller, E. M. Ramirez, and T. B. Murdock, "The influence of teachers' self-efficacy on perceptions: Perceived teacher competence and respect and student effort and achievement," Teaching and Teacher Education, vol. 64, pp. 260-269, May 2017.

[19] M. E. Türkoğlu, R. Cansoy, and H. Parlar, "Examining the relationship between teachers' self-efficacy and job satisfaction," Universal Journal of Educational Research, vol. 5, no. 5, pp. 765-772, 2017.

[20] G. V. Caprara, C. Barbaranelli, P. Steca, and P.S. Malone, "Teachers' self-efficacy beliefs as determinants of job satisfaction and students' academic achievement: A study at the school level," Journal of School Psychology, vol. 44, no. 6, pp.473-490, 2006.

[21] W. J. G. Evers, A. Brouwersand, and W. Tomic, "Burn out and self-efficacy: A study on teachers' beliefs when implementing an innovative educational system in the Netherlands," British Journal of Educational Psychology, vol. 72, no. 2, pp. 227-243, 2002.

[22] Ş. İlter, and B. Köksalan, "Primary school teacher candidates' attitudes towards teaching profession," Firat University, Social Sciences Journal, vol. 21, no. 1, pp. 113-128, 2011.

[23] F. Pajares, "Overview of social cognitive theory and self-efficacy," 2002. [Online]. Available: https://www.uky.edu/ eushe2/Pajares/eff.html

[24] B. Timur and N. Çetin, "Examining Self-Efficacy Beliefs and Attitudes of Pre-Service Science Teachers' and Pedogogical Proficiency Students' Towards Science Teaching Profession," International Journal of Active Learning, vol. 2, no. 2, pp. 15-27, 2017.

[25] H. Sivri and E. Balc1, "Pre-service teachers' classroom management self-efficacy beliefs," International Online Journal of Educational Sciences, vol. 7, no. 4, pp. 37-50, 2015.

[26] E. F. Bedel, "Exploring academic motivation, academic self-efficacy and attitudes toward teaching in early preservice childhood education teachers," Journal of Education and Training Studies, vol. 4, no. 1, pp. 142-149, 2016.

[27] M. D. Chester and B. Q. Beaudin, "Efficacy beliefs of newly hired teachers in urban schools," American Educational Research Journal, vol. 33, no. 1, pp. 233-257, 1996.

[28] C. İpek and F. Camadan, "Primary teachers' and primary pre-service teachers' self-efficacy beliefs and attitudes toward teaching profession," International Journal of Human Sciences [Online], vol. 9, no. 2, pp. 1206-1216, 2012.

[29] N. T. Bümen and T. E. Özaydın, "Changes on teacher self-efficacy and attitudes towards teaching profession from candidacy to induction," Education and Science, vol. 38, no. 169, pp. 109-125, 2013.

[30] N. Karasar, Scientific research methods, Ankara: Nobel, 2006.

[31] Raosoft, Sample size calculator, 2018. [Online]. Available: http://www.raosoft.com/samplesize.html

[32] D. Tepe, "Development of a declaratory scale for preschool teachers' self-efficacy beliefs," Unpublished masters thesis, Mehmet Akif Ersoy University Institute of Social Sciences, 2011.

[33] R. Zembat and N. H. Bilgin, "Investigation of Teaching Attitudes of Teachers Working in Preschool Education Institutions," National Education Symposium, Marmara University, Faculty of Education, pp.108-119, 1996.

[34] B. G. Tabachnick, and L. S. Fidell, Using multivariate statistics, Boston: Allyn and Bacon, 2007.

[35] D. George, and M. Mallery, SPSS for windows step by step: a simple guide and reference, 17.0 update. Boston: Pearson, 2010. 
[36] Ş. C. Emre, "Investigation of the relationship between secondary school teachers' self-efficacy beliefs and attitude towards teaching," Unpublished masters thesis, Kahramanmaraş Sütçü İmam University Institute of Social Sciences, 2017.

[37] Ş. Daştan, "Comparison of self-efficacy levels of preschool teachers and their attitudes towards the education of the gifted individuals," Unpublished masters thesis, Gazi University Institute of Educational Sciences, 2016.

[38] S. N. Toy, "The Comparison of self-efficacy and inclusive education beliefs of primary school teachers," Unpublished masters thesis, Pamukkale University Institute of Social Sciences, 2015.

[39] K. Korkut, "The correlation between level of classroom teachers? Self-efficacy beliefs and classroom management ability perceptions," Unpublished masters thesis, Mehmet Akif Ersoy University Institute of Social Sciences, 2009.

[40] E. Töre, "The effects of organizational climate on the knowledge management process," Turkish Studies Education, vol. 15, no. 3, pp. 2137-2151, 2020.

[41] R. C. Gürsoy, "Analyzing the effect of preschool teachers' self-esteem towards teaching attitude," Unpublished master's thesis, Marmara University Institute of Educational Sciences, 2009.

[42] E. Töre, "Internal sharing knowledge at professional development process: The workshop model," Marmara University Faculty of Education, Educational Sciences Journal, vol. 46, pp.133-150, 2017.

[43] E. Töre, "The effect of self-efficacy and internal locus of control on innovative work behavior: A research on the hospitality industry," Manas Journal of Social Studies, vol. 9, no. 1, pp.155-167, 2020. 